\title{
Plant species invasion effects on litter dynamics in subtropical streams
}

\author{
Efeitos da invasão de espécies vegetais na dinâmica da serapilheira em riachos \\ subtropicais
}

\section{Lucas Eugenio Fontana ${ }^{1,2 *}$ (D), Rozane Maria Restello² (D), Tanise Luisa Sausen² (D) and Luiz Ubiratan Hepp ${ }^{2}$}

'Programa de Pós-graduação em Ecologia, Universidade Federal de Santa Catarina - UFSC, Campus Universitário, Trindade, CEP 88040-900, Florianópolis, SC, Brasil

${ }^{2}$ Programa de Pós-graduação em Ecologia, Universidade Regional Integrada do Alto Uruguai e das Missōes - URI, Av. Sete de Setembro, 1621, CEP 99709-910, Erechim, RS, Brasil

*e-mail: lucaseugenio.fontana@yahoo.com.br

Cite as: Fontana, L. E. et al. Plant species invasion effects on litter dynamics in subtropical streams. Acta Limnologica Brasiliensia, 2020, vol. 32, e302.

Abstract: Aim: We evaluated the effect of the presence of Hovenia dulcis Thunb. (Rhamnaceae) in riparian zones on the organic matter dynamics of small subtropical streams. Methods: We conducted this study in three subtropical Atlantic Forest streams with different densities of $H$. dulcis in riparian vegetation located in southern Brazil. In each stream, we quantified the input of allochthonous organic matter for one year using buckets (area: $0.04 \mathrm{~m}^{2} /$ bucket) suspended about $1 \mathrm{~m}$ from the streambed in three different sections ( 15 buckets/stretch $=45$ buckets/stream). Monthly, the plant material retained in the buckets was collected individually, dried $\left(40 \pm 5^{\circ} \mathrm{C} / 72 \mathrm{~h}\right)$, identified (native litter together and $H$. dulcis litter alone) and weighed. Results: The largest input of native organic matter occurred during the winter months $\left(-55 \mathrm{~g} \cdot \mathrm{m}^{-2}\right)$, ranging from $-31 \mathrm{~g} \cdot \mathrm{m}^{-2}$ (summer) to $-46 \mathrm{~g} \cdot \mathrm{m}^{-2}$ (spring) over the year. The input of $H$. dulcis organic matter was concentrated in the autumn $\left(-56 \mathrm{~g} . \mathrm{m}^{-2}\right)$ and summer $\left(-28 \mathrm{~g} \cdot \mathrm{m}^{-2}\right)$, being scarce in the other seasons $\left(-3 \mathrm{~g} \cdot \mathrm{m}^{-2}\right.$ in the spring and winter). Only the contribution of native organic matter was associated with precipitation. Contrary to that observed with native vegetation (input of organic matter related with rainfall), $H$. dulcis input was related to the phenology of the species, which is deciduous, with leaf fall strongly marked, occurring especially during the autumn. Conclusions: When present at high densities (dominant), the presence of $H$. dulcis in riparian stream vegetation makes the supply of allochthonous plant resources scarce at some periods of the year, altering the energy availability in these ecosystems and, potentially, the functioning of subtropical streams.

Keywords: Atlantic Forest; biological invasion; exotic species; riparian zones.

Resumo: Objetivo: Avaliamos o efeito da presença de Hovenia dulcis Thunb. (Rhamnaceae) em zonas ripárias sobre a dinâmica da matéria orgânica de pequenos riachos subtropicais. Métodos: Realizamos este estudo em três riachos subtropicais de Mata Atlântica com diferentes densidades de $H$. dulcis na vegetação ripária localizados no sul do Brasil. Em cada riacho quantificamos o aporte de matéria orgânica alóctone durante um ano utilizando baldes (área: $0.04 \mathrm{~m}^{2} / \mathrm{balde}$ ) suspensos a cerca de $1 \mathrm{~m}$ do leito dos riachos em três trechos distintos ( 15 baldes/trecho $=45$ baldes/riacho). Mensalmente, o material vegetal retido nos baldes foi recolhido individualmente, seco $\left(40 \pm 5^{\circ} \mathrm{C} / 72 \mathrm{~h}\right)$, identificado (detritos nativos conjuntamente e detritos de $H$. dulcis isoladamente) e pesado. Resultados: Em média, 
o maior aporte de matéria orgânica nativa ocorreu durante os meses de inverno $\left(-55\right.$ g. $\left.\mathrm{m}^{-2}\right)$, tendo oscilado entre -31 g.m $\mathrm{m}^{-2}$ (veráo) e -46 g.m $\mathrm{m}^{-2}$ (primavera) ao longo do ano. O aporte de matéria orgânica de $H$. dulcis, entretanto, foi concentrada nos meses de outono $\left(-56\right.$ g.m $\left.\mathrm{m}^{-2}\right)$ e verão $\left(-28 \mathrm{~g} \cdot \mathrm{m}^{-2}\right)$, sendo escassa nas outras estaçóes do ano $\left(-3 \mathrm{~g} \cdot \mathrm{m}^{-2}\right.$ na primavera e no inverno). Apenas a contribuição da matéria orgânica nativa foi associada à precipitação mensal. A presença de $H$. dulcis alterou a dinâmica da matéria orgânica alóctone nos riachos. Ao contrário do observado com a vegetação nativa (aporte de matéria orgânica relacionada com a pluviosidade) o aporte de $H$. dulcis esteve relacionado com a fenologia da espécie, que é decídua e com queda foliar fortemente marcada, ocorrendo especialmente durante os meses de outono. Conclusóes: Quando presente em elevadas densidades (dominante), a presença de $H$. dulcis na vegetação ripária de riachos torna a oferta de recursos vegetais alóctones escassa em alguns períodos do ano alterando a disponibilidade de energia nesses ecossistemas e, potencialmente, o funcionamento de riachos subtropicais.

Palavras-chave: Mata Atlântica; invasão biológica; espécies exóticas; zonas ripárias.

\section{Introduction}

In small and shaded streams, the contribution of allochthonous organic matter is fundamental for the maintenance of aquatic communities because the primary productivity in these environments is limited by the shading generated by riparian vegetation (Graça, 2001; Neres-Lima et al., 2017). Within streams, the allochthonous organic matter is decomposed in a combination of chemical, physical and biological processes that result in its transformation and incorporation into the aquatic food chain (Webster \& Benfield, 1986; Marks, 2019). Therefore, the conservation of riparian vegetation is essential for the maintenance of fundamental ecosystem processes (e.g. nutrient cycling) and aquatic communities (Graça, 1993; Abelho, 2001; Graça et al., 2015).

Allochthonous organic matter originated by riparian vegetation is composed of leaves $(-60 \%$ to $80 \%$ of the total), branches $(-30 \%)$, and reproductive material (i.e. flowers and fruits) (Gonçalves Júnior \& Callisto, 2013; Rezende et al., 2017). The contribution of allochthonous organic matter to streams occurs in different ways (Gonçalves Júnior et al., 2006) and is influenced by the structure and composition of the riparian vegetation (França et al., 2009; Rezende et al., 2017). Many plant species contribute to the entry of organic matter into tropical (França et al., 2009; Gonçalves Júnior et al., 2014; Rezende et al., 2017; Jijón \& Molinero, 2019) and subtropical streams (Lisboa et al., 2015). Due to the specific phenology of tree species, the contribution of organic matter occurs in different periods, representing a constant energy input throughout the year in aquatic ecosystems (Lisboa et al., 2015; Rezende et al., 2017). Additionally, rainfall is considered the main climatic factor affecting the dynamics and input of organic matter on Brazilian streams (Lisboa et al., 2015; Rezende et al., 2016; Tonin et al., 2017).
The effect of exotic species presence on the ecosystems functioning is, currently, one of the main interest topics among ecologists (Sutherland et al., 2013). Many exotic species can occur associated with different aquatic ecosystems (Strayer, 2010). Specifically, the impact of exotic species on the functioning of streams, if existent, is still unclear and variable. In this context, the effect of the exotic species presence in the riparian vegetation of streams over, for example, ecosystem processes (e.g. decomposition of organic matter) and aquatic communities (e.g. aquatic invertebrates) are variable and can by positive, neutral or negative (CastroDíez \& Alonso, 2017). However, in the Iberian Peninsula, studies have shown that replacing native riparian vegetation (i.e. deciduous forest) with Eucalyptus monocultures alters the dynamics of organic matter in streams (Abelho \& Graça, 1996; Pozo et al., 1997; Graça et al., 2002; Molinero \& Pozo, 2004).

The exotic and invasive species Hovenia dulcis Thunb. (Rhamnaceae) has a high invasive capacity in native forest remnants (Meyer et al., 2012; Dechoum et al., 2015). Part of the successful establishment of $H$. dulcis is due to the allelopathic potential of its pseudo-fruits and leaves on seeds germination and seedling growth (Wandscheer et al., 2011) of native species (Ribeiro et al., 2019) and seeds dispersion by zoochory (pseudo-fruits are widely consumed, especially by mammals and birds) (Rocha et al., 2008; Hendges et al., 2012; Lima et al., 2015). The invasion of native forest remnants by $H$. dulcis, including protected areas and riparian zones in Brazil, has been reported in several studies (Zenni \& Ziller, 2011; König et al., 2014; Dechoum et al., 2015; Lazzarin et al., 2015; Padilha et al., 2015). However, knowledge about the effect of $H$. dulcis on aquatic ecosystems is still scarce. 
In this study, we sought to understand how the presence of $H$. dulcis in riparian zones affects the dynamics of organic matter in small order streams (i.e. streams in which allochthonous organic matter input is the main energy source). For this, we quantified the annual contribution of organic matter from native species and $H$. dulcis in subtropical streams. Our hypothesis is that the input of organic matter by native species is constant throughout the year and associated with periods of high rainfall while the input of organic matter by $H$. dulcis is concentrated at the period of the year associated with the deciduous foliar habit of the species.

\section{Material and Methods}

\subsection{Study area}

We performed this study in a forest remnant located in southern Brazil within a protected area (Parque Natural Municipal Mata do Rio Uruguai Teixeira Soares; $27^{\circ} 30^{\prime} 02^{\prime \prime S}$ and 51 $57^{\prime} 11^{\prime \prime W}$ ). This area is inserted in the Atlantic Forest biome, comprising a transition zone between Semideciduous Seasonal Forest and Atlantic Forest with Araucaria (Oliveira-Filho et al., 2015). The vegetation is characterized by an elevated diversity of tree species, specially of the families Lauraceae (e.g. Nectandra megapotamica (Spreng.) Mez, Ocotea puberula (Rich.) Nees, Ocotea odorifera (Vell.) Rohwer), Fabaceae (e.g. Parapiptadenia rigida (Benth.) Brenan, Dalbergia frutescens (Vell.) Britton, Inga marginata Willd. and Apuleia leiocarpa (Vogel) J.F. Macbr.), Euphorbiaceae (e.g. Gymnanthes concolor (Spreng.) Müll. Arg., Sebastiania commersoniana (Baill.) L.B. Sm. \& Downs and Sebastiania brasiliensis Spreng.), Sapindaceae (e.g. Allophylus edulis (A.St.-Hil, Cambess. \& A. Juss.) Radlk, Allophylus puberulus (Cambess.) Radlk. and Cupania vernalis Cambess.) and Meliaceae (e.g. Cedrela fissilis Vell., Trichilia elegans A. Juss. and Cabralea canjerana (Vell.) Mart.) (Socioambiental Consultores Associados, 2012). Additionally, H. dulcis Thunb. (Rhamnaceae) is commonly found within this protected area (Socioambiental Consultores Associados, 2012). The region is part of the Serra Geral geological formation and the climate is classified as humid subtropical (Köppen classification), with an annual mean temperature of $18^{\circ} \mathrm{C}$ and mean precipitation of $1900 \mathrm{~mm}$ (Alvares et al., 2013).

We selected three $\leq 2 \mathrm{a}$ order streams: PM

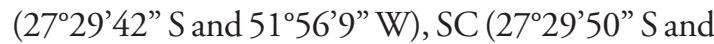

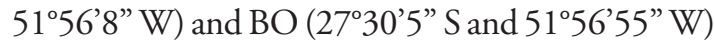
(approximate coordinates) (Figure 1). The selected

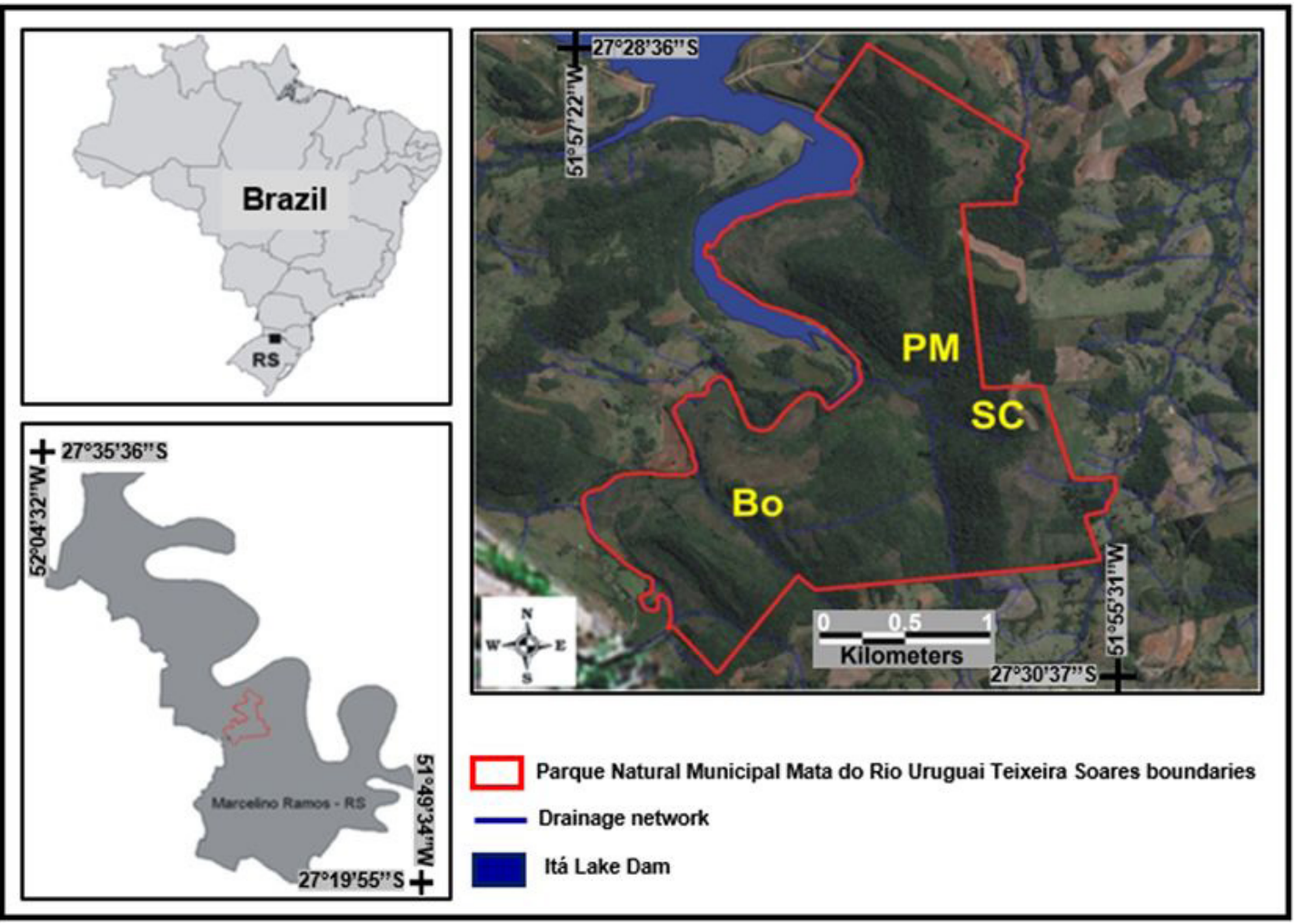

Figure 1. Geographic location of the three subtropical streams (PM, BO and SC) studied in southern Brazil. Prepared in collaboration with the Laboratório de Geoprocessamento e Planejamento Ambiental (URI Erechim). 
streams are morphologically similar with widths ranging between 0.5 and $2.0 \mathrm{~m}$ and depths $\leq 0.5 \mathrm{~m}$. Each stream has, at least, $50 \mathrm{~m}$ of riparian vegetation on each side bank. The riparian vegetation of each stream presents distinct densities of $H$. dulcis. We measured $H$. dulcis density in the riparian vegetation of each stream by counting the individuals with circumference at chest height $\geq 0.3 \mathrm{~m}$ from a two $10 \times 50 \mathrm{~m}$ plots (one in each stream margin). The BO stream presented the high density of $H$. dulcis on riparian vegetation (360 ind.ha ${ }^{-1}$ ) being followed by SC stream (230 ind.ha ${ }^{-1}$ ), while PM stream presented the lower $H$. dulcis density (10 ind.ha ${ }^{-1}$ ). The rainfall monthly data were obtained on a meteorological station located $8 \mathrm{Km}$ of the studied area.

\subsection{Allochthonous organic matter sampling}

In each stream, we quantified the contribution of total native and exotic allochthonous organic matter over one year (monthly, from June 2016 to May 2017), using methods adapted from Gonçalves Júnior \& Callisto (2013). We collected organic matter with buckets with perforated bottom for rainwater drainage (area $0.04 \mathrm{~m}^{2}$ per bucket) suspended about $1 \mathrm{~m}$ above the streambed in three sections located 15-20 m apart from each other. On each section we suspended 15 buckets, totaling 45 buckets per stream. Every month, we collected all the plant organic matter from each bucket individually, conditioned it on plastic bags and transported all samples to the laboratory for drying $\left(40 \pm 5^{\circ} \mathrm{C} / 72 \mathrm{~h}\right)$, identification and weighing. From the collected plant material, we considered a pool containing all the fractions of organic matter (i.e. leaves, branches, fruits, flowers, and seeds). We considered the pool of plant fractions as the total content of allochthonous organic matter since the main idea this study was to evaluate the total contribution of allochthonous organic matter to streams and not the individual contribution of distinct fractions. We identified the organic matter of $H$. dulcis and weighed it separately, while organic matter from native species was counted all together.

\subsection{Data analysis}

We compared the total annual input from native species and $H$. dulcis organic matter of the streams studied together using a paired t-test. Similarly, we compared the input from native species and $H$. dulcis organic matter of each stream individually using paired t-tests. In addition, we analyzed the monthly variation in the input of organic matter from native species and $H$. dulcis using an Analysis of Variance (two-way ANOVA), considering the streams (3 levels) and sampling months (12 levels) as factors. For the t-tests and ANOVA analyses, we tested the normality of the organic matter input data using a Shapiro-Wilk test. As the data were not in accordance with the normal distribution, we transformed them into $\ln (x+1)$ in order to reduce variability and to better correspond to the assumptions for performing parametric tests. Finally, we evaluated the association between monthly precipitation and inputs of organic matter from native species and $H$. dulcis using Pearson's correlation. Statistical analyses were performed using the statistical software R (R Core Team, 2019), using the "stats" package.

\section{Results}

The total annual (sum of streams) input of native organic matter and Hovenia dulcis, regardless of the three streams studied, was similar $\left(-1629 \mathrm{~g} \cdot \mathrm{m}^{-2}\right.$ and -873 g. $\mathrm{m}^{-2}$, respectively; $\mathrm{t}=1.0, \mathrm{df}=2, \mathrm{p}=0.40$ ). However, the total input of native and $H$. dulcis organic matter varied between streams (Figure 2). In the PM stream, the total input of native organic matter was greater than that of $H$. dulcis $\left(663.4 \mathrm{~g} \cdot \mathrm{m}^{-2}\right.$ and $14.3 \mathrm{~g} \cdot \mathrm{m}^{-2}$, respectively; $\mathrm{t}=-29.8, \mathrm{df}=35$, $\mathrm{p}<0.001)$. Similarly, in the BO stream, the total native input was higher than that of $H$. dulcis (616.9 g. $\mathrm{m}^{-2}$ and $327.0 \mathrm{~g} \cdot \mathrm{m}^{-2}$, respectively; $\mathrm{t}=-4.7$, $\mathrm{df}=35, \mathrm{p}<0.001)$. Finally, in the SC stream, the input of $H$. dulcis was greater than the input of native organic matter $\left(531.5 \mathrm{~g} \cdot \mathrm{m}^{-2}\right.$ and $348.8 \mathrm{~g} \cdot \mathrm{m}^{-2}$, respectively; $\mathrm{t}=-2.3, \mathrm{df}=35, \mathrm{p}=0.025)$.

The input of native organic matter varied among streams over months (Table 1). On mean, the highest organic matter input of native species occurred in the winter months (mean \pm standard error; $55.5 \pm 0.9$ g. $\mathrm{m}^{-2}$; Figure 2A-2D; Table 2), while spring $\left(46.2 \pm 6.5 \mathrm{~g} \cdot \mathrm{m}^{-2}\right)$, summer $\left(31.2 \pm 5.3 \mathrm{~g} . \mathrm{m}^{-2}\right)$ and autumn $\left(44.3 \pm 10.7 \mathrm{~g} \cdot \mathrm{m}^{-2}\right)$ months presented organic matter input slightly lower (Figure 2A-2D; Table 2). Additionally, PM $\left(55.3 \pm 4.4\right.$ g. $\mathrm{m}^{-2}$; Figure $\left.2 \mathrm{~A}\right)$ and $\mathrm{BO}$ streams $\left(48.3 \pm 6.2 \mathrm{~g} \cdot \mathrm{m}^{-2}\right.$; Figure $\left.2 \mathrm{C}\right)$ presented the greatest input of native species organic matter. Similarly, H. dulcis organic matter input also differed between streams over the months (Table 1). On mean, the highest $H$. dulcis organic matter input occurred in the autumn $\left(56.5 \pm 27.0\right.$ g. $\left.\mathrm{m}^{-2}\right)$ and summer $\left(28.1 \pm 17.8\right.$ g. $\left.\mathrm{m}^{-2}\right)$ months (Figure 2A-2D; Table 2). However, on winter $\left(2.0 \pm 0.7 \mathrm{~g} \cdot \mathrm{m}^{-2}\right)$ and spring $\left(2.0 \pm 0.8 \mathrm{~g} \cdot \mathrm{m}^{-2}\right)$ months the $H$. dulcis 


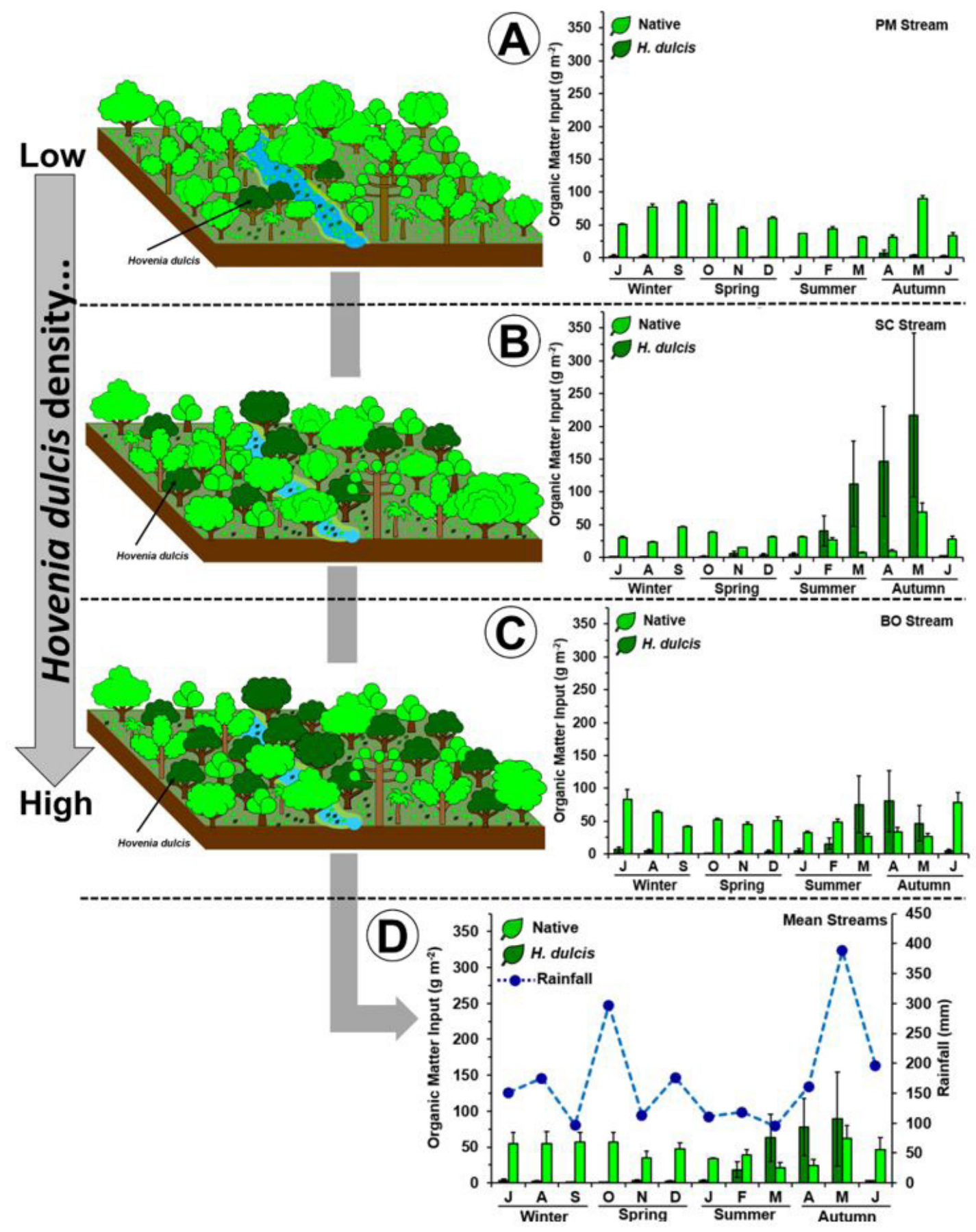

Figure 2. Monthly organic matter input (mean \pm standard error) of native species and $H$. dulcis in three subtropical streams with different $H$. dulcis densities on riparian vegetation: PM stream (A), SC stream (B) and BO stream (C). Also shown is the mean ( \pm standard error) organic matter input by the three streams and the monthly rainfall observed during the study period (D). (Initial "J": July 2016).

organic matter input presented a strongly decrease (Figure 2A-2D; Table 2).

The input of organic matter of native species was positively related to rainfall $(\mathrm{r}=0.60 ; \mathrm{df}=10$; $\mathrm{p}=0.04)$. On the other hand, we did not observe significant association between rainfall and $H$. dulcis organic matter input $(\mathrm{r}=0.13 ; \mathrm{df}=10 ; \mathrm{p}=0.68)$ (Figure 2D).

\section{Discussion}

The annual similar input of organic matter of native species and of Hovenia dulcis in the study area 
Table 1. Result of Analysis of Variance (two-way ANOVA) on organic matter input of native species and $H$. dulcis among streams and months. Degrees of freedom (df), sum of squares (SS), mean of squares (MS), test value (F) and test significance $(\mathrm{p})$ are described.

\begin{tabular}{lccccc}
\hline & df & SS & MS & F & p \\
\hline Native input & & & & & \\
Stream & 2 & 12.8 & 6.4 & 13.9 & $<0.001^{*}$ \\
Month & 11 & 19.9 & 1.8 & 3.4 & $<0.001^{*}$ \\
Stream:Month & 22 & 11.5 & 0.5 & 1.1 & 0.808 \\
Residuals & 72 & 33.1 & 0.5 & & \\
Hovenia dulcis input & & & & & \\
Stream & 2 & 50.7 & 25.4 & 63.4 & $<0.001^{*}$ \\
Month & 11 & 127.7 & 11.6 & 29.0 & $<0.001^{*}$ \\
Stream:Month & 22 & 61.3 & 2.8 & 6.9 & $<0.001^{*}$ \\
Residuals & 72 & 28.8 & 0.4 & & \\
\hline
\end{tabular}

$(*)$ Significant values for $\mathrm{p}<0.05$.

Table 2. Results of Tukey test carried a posteriori of the Analysis of Variance (two way ANOVA) to verify the difference of native and $H$. dulcis organic matter input between the months.

\begin{tabular}{|c|c|c|c|c|c|c|c|c|c|c|c|c|}
\hline Native & Jan & Feb & Mar & Apr & May & June & July & Aug & Sep & Oct & Nov & Dec \\
\hline Jan & - & & & & & & & & & & & \\
\hline Feb & 1.000 & - & & & & & & & & & & \\
\hline Mar & 0.315 & 0.239 & - & & & & & & & & & \\
\hline Apr & 0.240 & 0.177 & 1.000 & - & & & & & & & & \\
\hline May & 0.999 & 0.999 & 0.077 & 0.053 & - & & & & & & & \\
\hline June & 1.000 & 1.000 & 0.310 & 0.236 & 0.999 & - & & & & & & \\
\hline July & 0.999 & 0.999 & $0.048^{*}$ & $0.032^{*}$ & 1.000 & 0.999 & - & & & & & \\
\hline Aug & 0.992 & 0.997 & $0.020^{*}$ & $0.013^{*}$ & 0.999 & 0.993 & 1.000 & - & & & & \\
\hline Sep & 0.916 & 0.956 & $0.005^{*}$ & $0.003^{*}$ & 0.998 & 0.919 & 0.999 & 0.999 & - & & & \\
\hline Oct & 0.941 & 0.971 & $0.006^{*}$ & $0.004^{*}$ & 0.999 & 0.944 & 0.999 & 0.999 & 1.000 & - & & \\
\hline Nov & 1.000 & 0.999 & 0.485 & 0.391 & 0.998 & 1.000 & 0.994 & 0.960 & 0.794 & 0.839 & - & \\
\hline Dec & 0.999 & 0.999 & $0.046^{*}$ & $0.031^{*}$ & 1.000 & 0.999 & 1.000 & 1.000 & 0.999 & 0.999 & 0.993 & - \\
\hline \multicolumn{13}{|c|}{ H. dulcis } \\
\hline & Jan & Feb & Mar & Apr & May & June & July & Aug & Sep & Oct & Nov & Dec \\
\hline Jan & - & & & & & & & & & & & \\
\hline Feb & $0.031^{*}$ & - & & & & & & & & & & \\
\hline Mar & $<0.001^{*}$ & 0.258 & - & & & & & & & & & \\
\hline Apr & $<0.001^{*}$ & $0.001^{*}$ & 0.820 & - & & & & & & & & \\
\hline May & $<0.001^{*}$ & $0.015^{*}$ & 0.993 & 0.999 & - & & & & & & & \\
\hline June & 1.000 & $0.023^{*}$ & $<0.001^{*}$ & $<0.001^{*}$ & $<0.001^{*}$ & - & & & & & & \\
\hline July & 1.000 & 0.054 & $<0.001^{*}$ & $<0.001^{*}$ & $<0.001^{*}$ & 1.000 & - & & & & & \\
\hline Aug & 0.999 & $0.003^{*}$ & $<0.001^{*}$ & $<0.001^{*}$ & $<0.001^{*}$ & 0.999 & 0.998 & - & & & & \\
\hline Sep & 0.131 & $<0.001^{*}$ & $<0.001^{*}$ & $<0.001^{*}$ & $<0.001^{*}$ & 0.162 & 0.080 & 0.493 & - & & & \\
\hline Oct & 0.277 & $<0.001^{*}$ & $<0.001^{*}$ & $<0.001^{*}$ & $<0.001^{*}$ & 0.328 & 0.185 & 0.734 & 0.999 & - & & \\
\hline Nov & 0.999 & $0.005^{*}$ & $<0.001^{*}$ & $<0.001^{*}$ & $<0.001^{*}$ & 0.999 & 0.999 & 1.000 & 0.407 & 0.649 & - & \\
\hline Dec & 0.999 & $0.008^{*}$ & $<0.001^{*}$ & $<0.001^{*}$ & $<0.001^{*}$ & 0.999 & 0.999 & 1.000 & 0.312 & 0.549 & 1.000 & - \\
\hline
\end{tabular}

$\left(^{*}\right)$ Significant values for $\mathrm{p}<0.05$.

reveals the effect of the exotic species on organic matter dynamic in streams. The presence of $H$. dulcis in the riparian zone of streams has altered the allochthonous organic matter dynamic to streams, which may cause changes in these ecosystems functioning. These arguments are corroborated by the comparative results between the organic matter input of native species and $H$. dulcis in each stream individually. In SC and BO streams, $H$. dulcis density in the riparian zone was greater than in PM stream. Thus, the high abundance of $H$. dulcis greatly influenced the organic matter input in the streams, especially in SC stream, where $H$. dulcis input was significantly greater than native input. These results are ecologically relevant because, although higher when compared with native organic matter input in the SC stream, the $H$. dulcis organic matter input it was available in large quantities 
in only 3 or 4 months of the year. In this sense, a riparian zone with predominance of $H$. dulcis may generate an excessive organic matter input in a short period of the year, depleting the aquatic ecosystem from an allochthonous energy source for long periods.

The contribution of native organic matter was, on mean, slightly higher in the winter months and, then, in the spring and autumn months and was related to the rainfall. During the study period the rainfall was well distributed throughout the year, with peaks $\left(>200 \mathrm{~mm} \cdot \mathrm{months}^{-1}\right)$ in the October and May which may have contributed to the increase in the native organic matter input in the spring and autumn. In addition to rainfall, the pattern of native organic matter dynamics observed may also be related to the riparian vegetation composition, which, in the study region, is characterized by the occurrence of perennial, semi-deciduous and deciduous species (Loregian et al., 2012; Mélo et al., 2013). Thus, the native organic matter input was possibly related to the leaf habit and to a greater leaf fall of deciduous and semi-deciduous species (especially in the autumn / winter transition) or the replacement of senescent leaves for the appearance of new leaves in the growing season (especially in the winter / spring transition) (Athayde et al., 2009; Turchetto \& Fortes, 2014, Dick et al., 2015; Capellesso et al., 2016).

The contribution of organic matter of native species observed in this study was similar to the vertical contribution observed in another subtropical Atlantic Forest stream (Lisboa et al., 2015) and in a tropical stream of Cerrado (Leite et al., 2016), but was lower than that observed in tropical Atlantic Forest stream (Gonçalves Júnior et al., 2014). Although studies with this approach are relatively scarce in subtropical climates, our results highlight the influence of rainfall and temperature decrease on the contribution of terrestrial organic matter to subtropical streams.

The highest contribution of $H$. dulcis organic matter occurred during autumn and late summer. This result was clearly related to the deciduous foliar habit of this species, which has the highest leaf fall in autumn (Carvalho, 1994; Schumacher et al., 2008). Additionally, the high organic matter input of $H$. dulcis observed at the end of the summer (i.e. March) is related to the early occurrence of days with low temperatures like the days of autumn, anticipating the fall of the leaves. In Brazil, the literature indicates that the leaf fall period of $H$. dulcis is concentrated in the months of April-
May to August (i.e. autumn and winter) (Carvalho, 1994), but studies evaluating the production of $H$. dulcis litterfall are very scarce. The results of this study indicated that during the autumn, the contribution of $H$. dulcis was $27 \%$ higher than the contribution of native species. Unlike what is sometimes observed with Eucalyptus (low organic matter input when compared to the native deciduous organic matter input) (Graça et al., 2002; Molinero \& Pozo, 2004), H. dulcis effects at the organic matter dynamic are mainly related to the greater organic matter input during a restricted period of the year.

The occurrence of increased organic matter input (e.g. native or exotic) only in a short period of the year can affect the functioning of these ecosystems. In a broader context, $H$. dulcis has a high invasive capacity, especially in impacted forests remnants with high canopy openings, less species diversity and simplified communities structure (Dechoum et al., 2015; Lazzarin et al., 2015). Thus, in riparian zones with greater invasiveness of $H$. dulcis, especially where this species becomes dominant, $H$. dulcis presence may affect the organic matter dynamic of small streams because of its short period of abundant foliar fall. On the other hand, in streams that have native riparian vegetation, we observed a substantial presence of native organic matter during the whole study period, despite the greater contribution during winter and spring, which guarantees an "always present" energy supply in these streams (Lisboa et al., 2015).

Our results demonstrate that the invasion of H. dulcis in riparian zones may affect the dynamics of organic matter in streams, especially where this species is dominant on riparian vegetation. While the contribution of native species organic matter was relatively constant throughout the year, the contribution of $H$. dulcis occurred predominantly in a short period of the year (especially in autumn). This timely supply of organic matter makes the availability of allochthonous plant resources scarce for most of the year, compromising the maintenance of key ecosystem processes (e.g. nutrient cycling) and aquatic communities in these streams.

\section{Acknowledgements}

The authors are grateful to the Chico Mendes Institute for Biodiversity Conservation for the issuance of a Collection License (ICMBio; Collection License No. 53164-1), to the Parque Natural Municipal Mata do Rio Uruguai Teixeira Soares for the assistance during the field activities and 
the ENGIE Tractebel Energia for the provision of rainfall data. LEF is grateful for the scholarship grant (CAPES-PROSUP) linked to the Graduate Program in Ecology of the URI Erechim. LUH receives financial support from CNPq ( $n^{\circ}$ 421632/2016-0) and CNPq grants (no 305203/2017-7).

\section{References}

ABELHO, M. and GRAÇA, M.A.S. Effects of eucalyptus afforestation on leaf litter dynamics and macroinvertebrate community structure of streams in Central Portugal. Hydrobiologia, 1996, 324(3), 195-204. http://dx.doi.org/10.1007/BF00016391.

ABELHO, M. From litterfall to breakdown in streams: a review. The Scientific World Journal, 2001, 1, 656-680. http://dx.doi.org/10.1100/tsw.2001.103. PMid:12805769.

ALVARES, C.A., STAPE, J.L., SENTELHAS, P.C., GONÇALVES, J.L.M. and SPAROVEK, G. Köppen's climate classification map for Brazil. Meteorologische Zeitschrift (Berlin), 2013, 22(6), 711-728. http:// dx.doi.org/10.1127/0941-2948/2013/0507.

ATHAYDE, E.A., GIEHL, E.L.H., BUDKE, J.C., GESING, J.P.A. and EISINGER, S.M. Fenologia de espécies arbóreas em uma floresta ribeirinha em Santa Maria, sul do Brasil. Revista Brasileira de Biociências, 2009, 7(1), 43-51.

CAPELLESSO, E.S., SCROVONSKI, K.L., ZANIN, E.M., HEPP, L.U., BAYER, C. and SAUSEN, T.L. Effects of forest structure on litter production, soil chemical composition and litter-soil interactions. Acta Botanica Brasílica, 2016, 30(3), 329-335. http:// dx.doi.org/10.1590/0102-33062016abb0048.

CARVALHO, P.E.R. Ecologia, silvicultura e usos da uva-do-japão (Hovenia dulcis Thunberg). Colombo: Embrapa, 1994, 16 p., Circular Técnica, no. 23.

CASTRO-DÍEZ, P. and ALONSO, A. Effects of non-native riparian plants in riparian and fluvial ecosystems: a review for the Iberian Peninsula. Limnetica, 2017, 36(2), 525-541. http://dx.doi. org/10.23818/limn.36.19.

DECHOUM, M.S., CASTELLANI, T.T., ZALBA, S.M., REJMÁNEK, M., PERONI, N. and TAMASHIRO, J.Y. Community structure, succession and invasibility in a seasonal deciduous forest in southern Brazil. Biological Invasions, 2015, 17(6), 1697-1712. http:// dx.doi.org/10.1007/s10530-014-0827-6.

DICK, G., D'ÁVILA, M. and SCHUMACHER, M.V. Produção de serapilheira em fragmento de Floresta Estacional Subtropical na região norte do Rio Grande do Sul. Ecologia e Nutrição Florestal, 2015, 3(1), 1-8. https://doi.org/10.5902/2316980X16354.

FRANÇA, J.S., GREGÓRIO, R.S., DE PAULA, J.D., GONÇALVES JÚNIOR, J.F., FERREIRA, F.A. and CALLISTO, M. Composition and dynamics of allochthonous organic matter inputs and benthic stock in a Brazilian stream. Marine and Freshwater Research, 2009, 60(10), 990-998. http://dx.doi. org/10.1071/MF08247.

GONÇALVES JÚNIOR, J.F., FRANÇA, J.S. and CALLISTO, M. Dynamics of allochthonous organic matter in a tropical Brazilian headstream. Brazilian Archives of Biology and Technology, 2006, 49(6), 967-973. http://dx.doi.org/10.1590/S151689132006000700014.

GONÇALVES JÚNIOR, J.F. and CALLISTO, M. Organic-matter dynamics in the riparian zone of a tropical headwater stream in Southern Brazil. Aquatic Botany, 2013, 109, 8-13. http://dx.doi. org/10.1016/j.aquabot.2013.03.005.

GONÇALVES JÚNIOR, J.F., REZENDE, R.S., GREGÓRIO, R.S. and VALENTIN, G.C. Relationship between dynamics of litterfall and riparian plant species in a tropical stream. Limnologica, 2014, 44, 40-48. http://dx.doi.org/10.1016/j. limno.2013.05.010.

GRAÇA, M.A.S. Patterns and processes in detritus-based stream systems. Limnologica, 1993, 23(2), 107-114.

GRAÇA, M.A.S. The role of invertebrates on leaf decomposition in streams: a review. International Review of Hydrobiology, 2001, 86(4-5), 383-393. http://dx.doi. org/10.1002/1522-2632(200107)86:4/5<383::AIDIROH383>3.0.CO;2-D.

GRAÇA, M.A.S., FERREIRA, V., CANHOTO, C., ENCALADA, A.C., GUERRERO-BOLAÑO, F., WANTZEN, K.M. and BOYERO, L. A conceptual model of litter breakdown in low order streams. International Review of Hydrobiology, 2015, 100(1), 1-12. http://dx.doi.org/10.1002/iroh.201401757.

GRAÇA, M.A.S., POZO, J., CANHOTO, C. and ELOSEGI, A. Effects of Eucalyptus plantations on detritus, decomposers, and detritivores in streams. The Scientific World Journal, 2002, 2, 1173 1185. http://dx.doi.org/10.1100/tsw.2002.193. PMid:12805976.

HENDGES, C.D., FORTES, V.B. and DECHOUM, M.S. Consumption of the invasive alien species Hovenia dulcis Thumb. (Rhamnaceae) by Sapajus nigritus Kerr, 1792 in a protected area in southern Brazil. Revista Brasileira de Zoociências, 2012, 14(13), 255-260.

JIJÓN, N. and MOLINERO, J. Materia orgánica particulada gruesa bentónica en dos ríos tropicales de la región del Chocó de Ecuador. Limnetica, 2019, 38(2), 653-667. http://dx.doi.org/10.23818/ limn.38.38.

KÖNIG, R., HEPP, L.U. and SANTOS, S. Colonisation of low- and high-quality detritus by benthic macroinvertebrates during leaf breakdown in a subtropical stream. Limnologica, 2014, 45, 61-68. http://dx.doi.org/10.1016/j.limno.2013.11.001. 
LAZZARIN, L.C., SILVA, A.C., HIGUCHI, P., SOUZA, K., PERIN, J.E. and CRUZ, A.P. Invasão Biológica por Hovenia dulcis Thunb. Em Fragmentos Florestais na Regiâo do Alto Uruguai, Brasil. Revista Árvore, 2015, 39(6), 1007-1017. http://dx.doi. org/10.1590/0100-67622015000600003.

LEITE, G.F.M., SILVA, F.T.C., NAVARRO, F.K.S.P., REZENDE, R.S. and GONÇALVES JÚNIOR, J.F. Leaf litter input and electrical conductivity may change density of Phylloicus sp. (Trichoptera: Calamoceratidae) in a Brazilian savannah stream. Acta Limnologica Brasiliensia, 2016, 28(0), e12. http:// dx.doi.org/10.1590/S2179-975X1516.

LIMA, R.E.M., DECHOUM, M.S. and CASTELLANI, T.T. Native seed dispersers may promote the spread of the invasive Japanese raisin tree (Hovenia dulcis Thunb.) in seasonal deciduous forest in southern Brazil. Tropical Conservation Science, 2015, 8(3), 846-862. http://dx.doi.org/10.1177/194008291500800318.

LISBOA, L.K., SILVA, A.L.L., SIEGLOCH, A.E., GONÇALVES JÚNIOR, J.F. and PETRUCIO, M.M. Temporal dynamics of allochthonous coarse particulate organic matter in a subtropical Atlantic Rainforest Brazilian stream. Marine and Freshwater Research, 2015, 66(8), 674-680. http://dx.doi. org/10.1071/MF14068.

LOREGIAN, A.C., SILVA, B.B., ZANIN, E.M., DECIAN, V.S., HENKE-OLIVEIRA, C. and BUDKE, J.C. Padrôes espaciais e ecológicos de espécies arbóreas refletem a estrutura em mosaicos de uma floresta subtropical. Acta Botanica Brasílica, 2012, 26(3), 593-606. http://dx.doi.org/10.1590/ S0102-33062012000300009.

MARKS, J. Revisiting the fates of dead leaves that fall into streams. Annual Review of Ecology, Evolution, and Systematics, 2019, 50, 547-568. https://doi. org/10.1146/annurev-ecolsys-110218-024755.

MÉLO, M.A., BUDKE, J.C. and HENKE-OLIVEIRA, C. Relationships between structure of the tree component and environmental variables in a subtropical seasonal forest in the upper Uruguay River valley, Brazil. Acta Botanica Brasilica, 2013, 27(4), 751-760. http://dx.doi.org/10.1590/S010233062013000400015.

MEYER, L., VIBRANS, A.C., GASPER, A.L., LINGNER, D.V. and SAMPAIO, D.K. Espécies exóticas encontradas nas florestas de Santa Catarina. In: A.C. VIBRANS, L. SEVEGNANI, A.L. GASPER and D.V. LINGNER, eds. Inventário Florístico Florestal de Santa Catarina: diversidade e conservação dos remanescentes florestais. Blumenau: Edifurb, 2012, pp. 236-265. vol. 1.

MOLINERO, J. and POZO, J. Impact of a eucalyptus (Eucalyptus globulus Labill.) plantation on the nutrient content and dynamics of coarse particulate organic matter (CPOM) in a small stream. Hydrobiologia,
2004, 528(1-3), 143-165. http://dx.doi.org/10.1007/ s10750-004-2338-4.

NERES-LIMA, V., MACHADO-SILVA, F., BAPTISTA, D.F., OLIVEIRA, R., ANDRADE, P.M., OLIVEIRA, A.F., SASADA-SATO, C.Y., SILVA-JÚNIOR, E.F., FEIJÓ-LIMA, R., ANGELINI, R., CAMARGO, P.B. and MOULTON, T.P. Allochthonous and autochthonous carbon flows in food webs of tropical forest streams. Freshwater Biology, 2017, 62(6), 10121023. http://dx.doi.org/10.1111/fwb.12921.

OLIVEIRA-FILHO, A., BUDKE, J.C., JARENKOW, J.A., EISENLOHR, P.V. and NEVES, D.R.M. Deving into the variations in tree species composition and richness across South American subtropical Atlantic and Pampean forest. Journal of Plant Ecology, 2015, 6(3), 242-260. http://dx.doi.org/10.1093/ jpe/rtt058.

PADILHA, D.L., LOREGIAN, A.C. and BUDKE, J.C. Forest fragmentation does not matter to invasions by Hovenia dulcis. Biodiversity and Conservation, 2015, 24(9), 2293-2304. http://dx.doi.org/10.1007/ s10531-015-0930-8.

POZO, J., GONZÁLEZ, E., DÍEZ, J.R., MOLINERO, $\mathrm{J}$. and ELÓSEGUI, A. Inputs of particulate organic matter to streams with different riparian vegetation. Journal of the North American Benthological Society, 1997, 16(3), 602-611. http://dx.doi. org/10.2307/1468147.

R CORE TEAM. $R$ : A language and environment for statistical computing [online]. Vienna: R Foundation for Statistical Computing, 2019 [viewed 29 Sep. 2019]. Available from: https://www.R-project.org/

REZENDE, R.S., GRAÇA, M.A., DOS SANTOS, A.M., MEDEIROS, A.O., SANTOS, P.F., NUNES, Y.R. and GONÇALVES JÚNIOR, J.F. Organic matter dynamics in a tropical gallery forest in a grassland landscape. Biotropica, 2016, 48(3), 301310. http://dx.doi.org/10.1111/btp.12308.

REZENDE, R.S., SALES, M.A., HURBATH, F., ROQUE, N., GONÇALVES JÚNIOR, J.F. and MEDEIROS, A.O. Effect of plant richness on the dynamics of coarse particulate organic matter in a Brazilian Savannah stream. Limnologica, 2017, 63, 57-64. http://dx.doi.org/10.1016/j. limno.2017.02.002.

RIBEIRO, V.M., VALMORBIDA, R., HARTMANN, K.C.D., PORTO, E.C., ALMEIDA, J., CORSATO, J.M. and FORTES, A.M.T. Efeito alelopático de Leucaena leucocephala e Hovenia dulcis sobre germinação de Mimosa bimucronata e Peltophorum dubium. Iheringia. Série Botânica, 2019, 74, e2019006. http://dx.doi.org/10.21826/244682312019v74e2019006.

ROCHA, V.J., AGUIAR, L.M., SILVA-PEREIRA, J.E., MORO-RIOS, R.F. and PASSOS, F.C. Feeding habits of the crab-eating Fox, Cerdocyon thous (Carnivora: Canidae), in a mosaic area with native 
and exotic vegetation in Southern Brazil. Revista Brasileira de Zoologia, 2008, 25(4), 594-600. http:// dx.doi.org/10.1590/S0101-81752008000400003.

SCHUMACHER, M.V., BRUN, E.J., ILLANA, V.B., DISSIUTA, S.I. and AGNE, T.L. Biomassa e Nutrientes em um Povoamento de Hovenia dulcis Thunb., plantado na FEPAGRO Florestas, Santa Maria, RS. Ciência Florestal, 2008, 18(1), 27-37. http://dx.doi.org/10.5902/19805098519.

S OCIOAMBIENTAL CONSULTORES ASSOCIADOS. Plano de Manejo do Parque Natural Municipal Mata do Rio Uruguai Teixeira Soares Marcelino Ramos/RS. Florianópolis: Socioambiental Consultores Associados, 2012, 213 p.

STRAYER, D.L. Alien species in fresh waters: ecological effects, interactions with other stressors, and prospects for the future. Freshwater Biology, 2010, 55, 152-174. Supplement 1. http://dx.doi.org/10.1111/j.13652427.2009.02380.x.

SUTHERLAND, W.J., FRECKLETON, R.P., GODFRAY, H.C.J., BEISSINGER, S.R., BENTON, T., CAMERON, D.D., CARMEL, Y., COOMES, D.A., COULSON, T., EMMERSON, M.C., HAILS, R.S., HAYS, G.C., HODGSON, D.J., HUTCHINGS, M.J., JOHNSON, D., JONES, J.P.G., KEELING, M.J., KOKKO, H., KUNIN, W.E., LAMBIN, X., LEWIS, O.T., MALHI, Y., MIESZKOWSKA, N., MILNER-GULLAND, E.J., NORRIS, K., PHILLIMORE, A.B., PURVES, D.W., REID, J.M., REUMAN, D.C., THOMPSON, K., TRAVIS, J.M.J., TURNBULL, L.A., WARDLE, D.A. and WIEGAND, T. Identification of 100 fundamental ecological questions. Journal of Ecology, 2013, 101(1), 58-67. http://dx.doi. org/10.1111/1365-2745.12025.

TONIN, A.M., GONÇALVES JÚNIOR, J.F., BAMBI, P., COUCEIRO, S.R.M., FEITOZA, L.A.M., FONTANA, L.E., HAMADA, N., HEPP, L.U.,
LEZAN-KOWALCZUK, V.G., LEITE, G.F.M., LEMES-SILVA, A.L., LISBOA, L.K., LOUREIRO, R.C., MARTINS, R.T., MEDEIROS, A.O., MORAIS, P.B., MORETTO, Y., OLIVERIA, P.C.A., PEREIRA, E.B., FERREIRA, L.P., PÉREZ, J., PETRUCIO, M.M., REIS, D.F., REZENDE, R.S., ROQUE, N., SANTOS, L.E.P., SIEGLOCH, A.E., TONELLO, G. and BOYERO, L. Plant litter dynamics in the forest-stream interface: precipitation is a major control across tropical biomes. Scientific Reports, 2017, 7, 1-14. https://doi.org/10.1038/ s41598-017-10576-8.

TURChETTO, F. and FORTES, F.O. Aporte e decomposição de serapilheira em Floresta Estacional Decidual na regiáo do Alto Uruguai, RS. Pesquisa Florestal Brasileira, 2014, 34(80), 391-397. http:// dx.doi.org/10.4336/2014.pfb.34.80.735.

WANDSCHEER, A.C.D., BORELLA, J., BONATTI, L.C. and PASTORINI, L.H. Atividade alelopática de folhas e pseudofrutos de Hovenia dulcis Thunb. (Rhamnaceae) sobre a germinação de Lactuca sativa L. (Asteraceae). Acta Botanica Brasilica, 2011, 25(1), 25-30. http://dx.doi.org/10.1590/S010233062011000100005.

WEBSTER, J.R. and BENFIELD, E.F. Vascular plant breakdown in freshwater ecosystems. Annual Review of Ecology and Systematics, 1986, 17(1), 567-594. http://dx.doi.org/10.1146/annurev. es.17.110186.003031.

ZENNI, R.D. and ZILLER, S.R. An overview of invasive plants in Brazil. Brazilian Journal of Botany, 2011, 34(3), 431-446. http://dx.doi.org/10.1590/S010084042011000300016 .

Received: 29 September 2019 Accepted: 17 August 2020

Associate Editors: Fabiana Schneck. 